\title{
Language study
}

97-273 Andrijašević, Marin (Zagreb U.). Kako hrvatski danas zrcali strane jezike? [Current reflections on foreign language units in Croatian.] Strani Jezici (Zagreb), 24, 3-4 (1995), 144-8.

This article discusses the prevailing treatment that foreign lexical units receive within the Croatian language system, both in the case of internationalisms and so-called recent loans. These are often denied admittance to the Croatian language corpus on an a priori basis. The author expresses his uneasiness at such an attitude, but also points out that, when foreign lexical units are borrowed, at least two factors should not be

neglected - as they often are: (a) the unit's communicative value and (b) the norms of phonemic and graphemic transference of such words. The author's views are illustrated by a discussion of two texts: an article in the Vjesnikov jezicni savjetnik series (a regular language column in the Croatian daily Vjesnik) and the text of an advertisement in the same newspaper.

97-274 Bullock, Barbara E. (Pennsylvania State U.). Popular derivation and linguistic inquiry: les javanais. The French Review (Champaign, IL), 70, 2 (1996), 180-91.

The term javanais refers to secret languages that hide the form of a base word through affixation (infixing javanais), through the displacement of sound segments (verlan), or through a combination of both (largjoni des louchébèms). Recently, linguists have become interested in javanais as a possible source of corpus-external evidence that can reveal a speaker's internalised knowledge of French. This article shows how this marks a shift in the nature of linguistic inquiry. It also considers the value of these javanais as external evidence of how the phonological and morphological components of French build a language's vocabulary.

\section{7-275 Rodríguez González, Félix (U. of Alicante, Spain). Functions of anglicisms in contemporary Spanish. Cahiers de Lexicologie (Paris), 68, (1996-1), 107-28.}

This article examines the causes and functions of anglicisms in contemporary (European) Spanish. The author reviews the traditional structural approaches from which lexicological studies largely derive, and also touches on the approaches of other disciplines such as text linguistics and sociolinguistics. The terminological framework of this study is mainly borrowed from Halliday's functional methodology, in the way it was applied by Rakusan in his study of American Czech. The data used in the present study come from lexicographical sources, especially from Spanish newspapers such as El Pais and El Mundo.

97-276 Sakaguchi, Alicja (Goethe-U., Frankfurt am Main, Germany). Die Dichotomie 'künstlich' vs. 'natürlich' und das historische Phänomen einer funktionierenden Plansprache. [The 'natural' vs. 'artificial' dichotomy and the historical phenomenon of a functioning invented language.] Language Problems and Language Planning (Amsterdam), 20, 1 (1996), 18-38.

This article seeks to apply to Esperanto the ideas about language in general formulated by Rudi Keller in his book Sprachwandel [Language Change]. Keller claimed that so-called 'natural' languages were neither natural nor artificial, but best regarded as 'phenomena of the third kind', dynamic and 140 historically evolving. Sakaguchi argues that Esperanto, which began as a pure artefact, has developed as one of the natural means of communication of a worldwide 'diaspora' community, and so it too now qualifies as a 'phenomenon of the third kind'. 
97-277 dos Santos, Mauro Bittencourt (Santa Catarina U., Brazil). The textual organisation of research paper abstracts in applied linguistics. Text (Berlin), 16, 4 (1996), 481-99.

Research paper abstracts are an important site for the visibility of scientific endeavour. However, little research has been carried out on how abstracts can be characterised in terms of their textual organisation and other key features. In addition, advice available in technical writing literature seems to be of little avail to the production of quality abstracts. To help remedy this deficiency, this study investigates the actual discourse organisation of 94 abstracts in three leading journals from the field of applied linguistics. A move analysis reveals that abstracts follow a fivemove pattern, namely: Move 1 motivates the reader to examine the research by setting the general field or topic and stating the shortcomings of previous study; Move 2 introduces the research by either making a descriptive statement of the article's main focus or by presenting its purpose; Move 3 describes the study design; Move 4 states the major findings; and Move 5 advances the significance of the research by either drawing conclusions or offering recommendations. This descriptive analysis concludes that actual practice does not coincide with the advice available in manuals. The proposed pattern may serve as a pedagogic tool to help researchers in writing informative abstracts and, beyond that, in entering the mainstream of research debate.

\section{7-278 Thompson, Geoff (U. of Liverpool). Voices in the text: discourse perspectives on language reports. Applied Linguistics (Oxford), 17, 4 (1996), 501-30.}

This paper investigates the ways in which language events are reported in English. Language reports are identified on functional rather than structural grounds. The definition that is used for identification is 'signalled voices in text', and the framework suggested here attempts to account for all instances in naturally-occurring text which are covered by such a definition. Four main dimensions of choice for the reporter in any language report are outlined and exemplified: the voice that is presented as the source of the report, the way in which the message is reported, the reporting signal, and the reporter's attitude. Some possible applications of the framework are outlined. 